\title{
PROPPANT SZEMCSÉK MIKROMECHANIKAI PARAMÉTEREINEK MEGHATÁROZÁSA
}

\author{
Lengyel Tamás ${ }^{a}$, Varga Attila ${ }^{b^{*}}$
}

a MOL Petrolkémiai Zrt., általános üzemirányító

b Knorr-Bremse VJRH Kft., számítási mérnök

\begin{abstract}
ABSZTRAKT
Munkánk során a hidraulikus rétegrepesztésnél használt kitámasztó anyag (proppant) mikromechanikai paramétereit határoztuk meg a YADE nyílt forrás kódú és az EDEM Academic diszkrét elemes szoftverek segítségével. A paraméter identifikációs technikák közül a siló kifolyást választottuk. A kísérleti vizsgálatok során a silóból kifolyt szemcsehalmaz tömegét mértük az idô függvényben és minden esetben meghatároztuk az átlagos kifolyási tömegáramot. A numerikus és a kísérleti úton kapott tömegáramok összehasonlításánál azt tapasztaltuk, hogy az általunk meghatározott mikromechanikai paraméterek alkalmasak a proppant szemcsék mechanikai viselkedésének leírására.
\end{abstract}

Kulcsszavak: hidraulikus rétegrepesztés, diszkrét elemes módszer, proppant

\section{Bevezetés}

A hidraulikus rétegrepesztés egy rétegkezelési eljárás, mellyel az elsósorban gyenge hozammal rendelkező kutak produktivitását lehet jelentôsen javítani. Jelenleg ez technológia a leghatásosabb stimulációs eljárás az olajiparban [1]. A repesztést a felszínen, nagy nyomású szivattyúk segítségével inicializálják, azonban valójában a mélyben, általában közel a kúttalphoz, a szénhidrogént tartalmazó rétegben hozzák létre. A szivattyúzott repesztő fluidum 99\%-ban vizet, a maradék 1\%-ban pedig adalékanyagokat tartalmaz. Az adalékanyagok elsôsorban a fluidum reológiai tulajdonságának beállításáért felelnek. Megfelelően viszkózus közeg létrehozása a cél annak érdekében, hogy a múvelet során a folyadék a magasabb viszkozitás miatt nyomásemelkedést hozzon létre és képes legyen mechanikai feszültség generálásra [2]. A feszültség következtében a tároló kôzetmechanikai tulajdonságai miatt megreped. Ez a repedés, a repesztő fluidum által létrehozott nyomás hatására tovább terjed a tárolóban a kốzetfeszültségi irányoknak megfelelően (1. ábra). A hidraulikus nyomás megszûnése előtt az így kialakított repedéseket úgynevezett proppant szemcsékkel szükséges kitámasztani. A proppant szemcsékkel nagyságrendekkel növelhetô a formáció áteresztóképessége. Az eljárás befejeztével tisztító termeltetés következik, mely során a repesztő fluidum visszaszivattyúzása történik.

A vizsgált jelenség a rétegrepesztés során, illetve gyakorlatilag közvetlen utána zajlik le, mikor a felszíni szivattyúzási nyomás megszúnik. Ekkor a repesztő folyadék az áramlástani viszonyoknak megfelelően kiszứrődik a rétegbe, amíg be nem áll az egyensúly a kőzetnyomás illetve a repedésben kialakult hidraulikus nyomás között. Az egyensúlyi állapot után a rétegnyomás az „eredeti viszonyoknak megfelelően" meghaladja a repedésben uralkodó hidraulikus nyomást, így a kőzet a dinamikai viszonyoknak megfelelóen visszazáródik. A repesztés során a repedésbe szivattyúzott proppant szemcsék feladata a záródási folyamat megakadályozása. Az általunk vizsgált jelenség pedig ebben az idôlépcsóben kialakult állapot, azaz kőzetzáródás hatására a proppant szemcsék deformációja, illetve a kôzetbe való beágyazódása.

(C) ELTE, Informatikai Kar, Savaria Műszaki Intézet, 2021

*Kapcsolattartó: Varga Attila, attila.varga@knorr-bremse.com

https://doi.org/10.37775/EIS.2021.1.1 


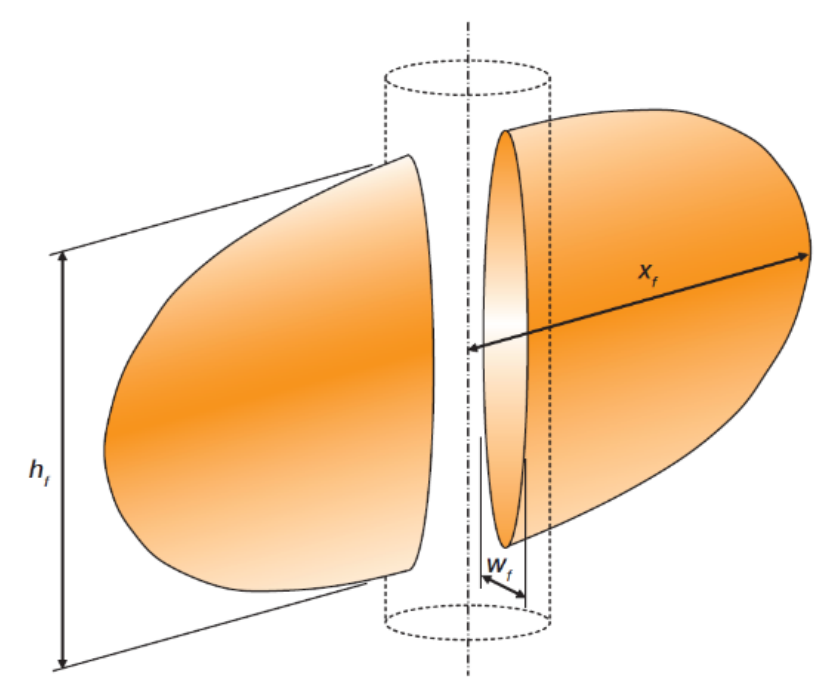

1. ábra. A repedés sematikus ábrája a kútban $\left(h_{f}, w_{f}\right.$ a repedésszélesség és $x_{f}$ a repedéshossz) [3]

A kutatási problémát alapvetően kétféle módszerrel lehet megvizsgálni. Az egyik a korábban használt analitikus módszer, a másik pedig a numerikus modellezés. Az analitikus módszer, melyet korábbi munkánkban [4] használtunk a Hertz-féle kontakt elméletből [5] vezethetô le, melyet a repedés szélesség-változás vizsgálatára Li és társai [6] használtak először. Az analitikus megoldás viszonylag egyszerú, ugyanakkor határokat szab a probléma pontos leírásának. A numerikus modellezés ezzel szemben a problémának megfelelően összetett, azonban képes figyelembe venni bizonyos tényezóket, melyet az analitikus módszer nem. Ilyenek: a proppant szemcse nem ideális alakja, valamint mérettartományon belüli szemcseméret szórása, a szemcsék elhelyezkedésének véletlenszerú jellege stb.

Feltevésünk szerint a diszkrét elemes módszer (DEM) alkalmas lehet a hidraulikus repesztés modellezésére. Ennek elsố lépése a proppant szemcsehalmaz mikromechanikai paramétereinek meghatározása. Jelen tanulmány ezen mikromechanikai paraméterek meghatározási módját mutatja be.

\section{Diszkrét elemes modellezés}

A diszkrét elemes módszert a szemcsehalmazok mechanikai viselkedésének leírására hozták létre. Egy numerikus eljárást diszkrét elemes modellnek tekinthetünk, ha egymástól egyértelmüen elkülöníthető elemekból épül fel, és ezek az elemek önálló elmozdulási szabadságfokokkal rendelkeznek oly módon, hogy a modell képes követni az elemek véges nagyságú eltolódásait és elfordulásait (esetleg deformációit is). A modellt alkotó elemek között új kapcsolatok jöhetnek létre és meglévô kapcsolatok szúnhetnek meg és a topológia ezen változásai automatikusan nyomon követhetők a számítások során [7]. A számítások eredménye részben a rendszer geometriai jellemzôitôl (szemcsealak, szerkezeti elemek alakja), részben a diszkrét elemek közötti (mechanikai) kapcsolatoktól függ. A diszkrét elemes szoftverek kapcsolati modelleket használnak az elemek közötti kölcsönhatások (erôk, nyomatékok) leírására. A kapcsolati modellek állandóit mikromechanikai paramétereknek nevezzük. A diszkrét elemes modellezésnél az egyik a legnehezebb feladatot ezen paraméterek meghatározása jelenti (némelyik közvetlenül nem is mérhető). A legtöbb esetben a kalibrációs folyamat több idôt vesz igénybe, mint a modell felépítése, futtatása és kiértékelése együttvéve. Meghatározásukhoz ún. paraméter identifikációs technikákat szoktak alkalmazni [8]. Vizsgálatainkat az EDEM Academic és a Yade nyílt forráskódú szoftverkörnyezetben végeztük. Az EDEM szoftverben a kohéziómentes anyaghalmazok modellezésénél már bevált Hertz-Mindlin kapcsolati modellt alkalmaztunk (2. ábra), melynek részletes leírása megtalálható [9]-ben. 


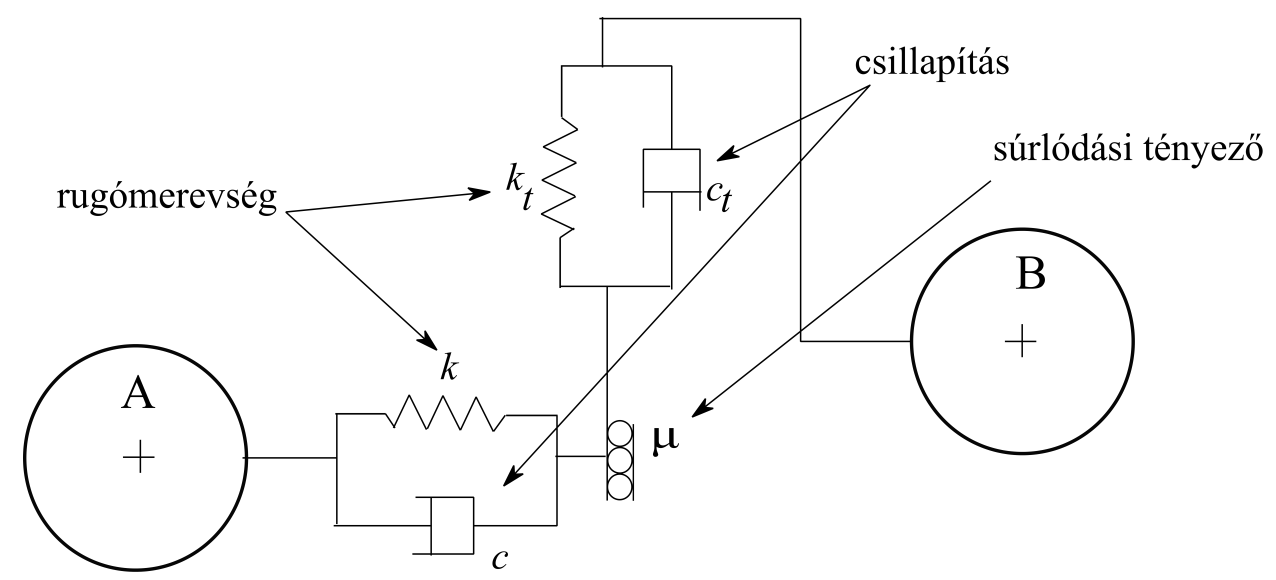

2. ábra. A Hertz-Mindlin kapcsolati modell [9]

A keresett mikromechanikai paraméterek a következők:

- Poisson-tényező $(\mu)$,

- csúsztató rugalmassági modulus $(G)$,

- sứrüség $(\rho)$,

- ütközési tényező $\left(C_{r}\right)$,

- statikus súrlódási tényező $\left(\mu_{0}\right)$,

- gördülési ellenállás tényező $\left(\mu_{r}\right)$.

YADE szoftverkörnyezetben úgynevezett BALL típusú modellt alkalmaztunk. Ebben az esetben a megoldó két sorosan kapcsolt rugó merevségéból számolja a kapcsolat normál merevségét (3. ábra). A BALL típusú modell részletes leírása megtalálható [10]-ben.

A YADE-ban keresett mikromechanikai paraméterek:

- Young-modulus $(E)$,

- Poisson-tényezô $(\mu)$,

- sứrüség $(\rho)$,

- ütközési tényező $\left(C_{r}\right)$,

- súrlódási szög $(\varphi)$,

- gördülési ellenállás tényező $\left(\mu_{r}\right)$.

A szimulációk során a megoldó a lendület- és perdülettételt alkalmazva felírja az egyes szemcsék mozgásegyenletét, majd az így keletkezô differenciálegyenlet rendszert oldja meg kis idóléptékek sorozatán keresztül. Az idôléptéknek nagy hatása van a numerikus modell stabilitására.

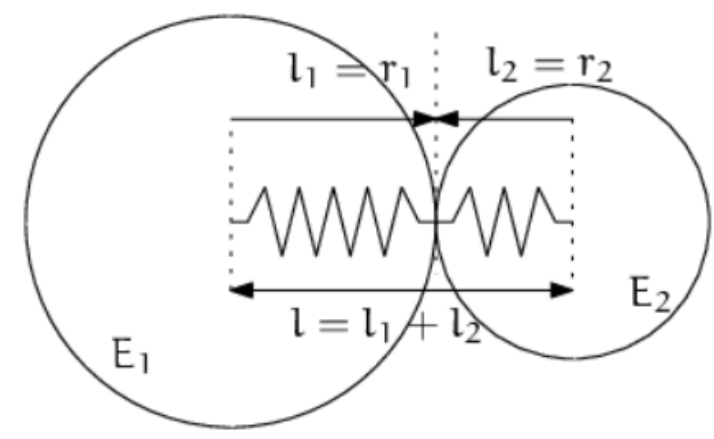

3. ábra. A BALL típusú modell YADE szoftverkörnyezetben [10] 


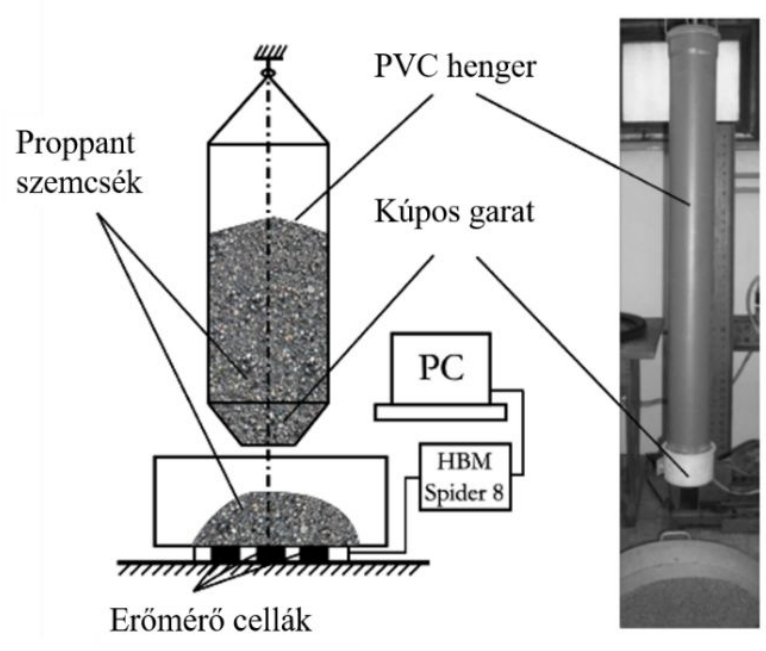

4. ábra. A mérốrendszer összeállítása [11]

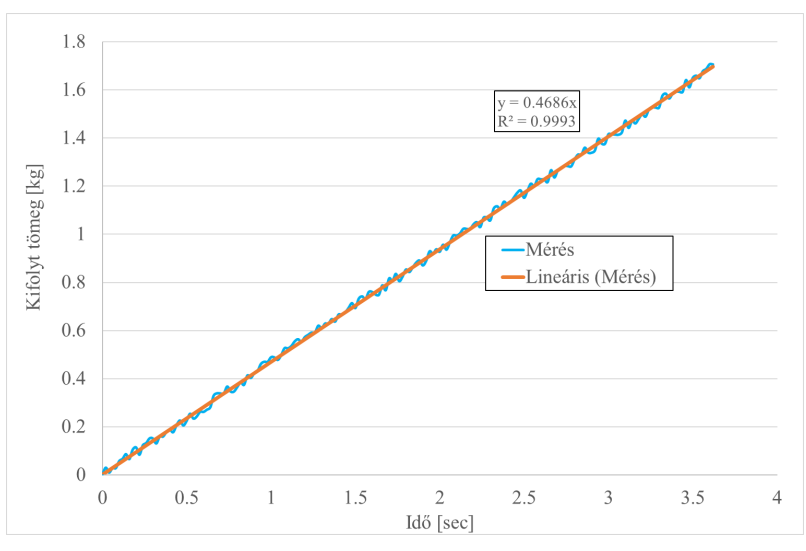

5. ábra. A mért tömeg-idő függvény

\section{Kísérleti vizsgálatok}

A legelterjedtebb paraméter identifikációs vizsgálatok a nyíróvizsgálat és a siló kifolyás. Munkánk során a siló kifolyást választottuk. A hengeres silók kifolyásának kísérleti vizsgálatát a (4. ábrán) látható mérő- és adatfeldolgozó rendszerrel ellátott modellsilóval végeztük. A modellsiló egy $110 \mathrm{~mm}$ átmérôjú, $700 \mathrm{~mm}$ hosszúságú PVC henger, amelyhez $35 \mathrm{~mm}$ átmérőjú kifolyónyílással ellátott kúpos kialakítású garat csatlakozik. A garat félkúp szöge $60^{\circ}$ volt. A vizsgált anyaghalmaz tömege 1,7 kg. A kifolyt tömeget 3 HBM (Hottinger Baldwin Messtechnik) C9B erômérố cellával mértük. Az adatfeldolgozást a HBM Spider típusú 8 csatornás mérôerôsítô- és adatgyújtő egység végezte (4. ábra).

Az alkalmazott mintavételi frekvencia $50 \mathrm{~Hz}$ volt. Az adatfeldolgozás során az összetartozó tömegidő adatokat közös koordináta-rendszerben ábrázoltuk és minden esetben meghatároztuk az átlagos kifolyási tömegáramot. A jelenség lineáris jellege miatt kézenfekvô megoldás volt a lineáris regresszió alkalmazása (5. ábra). A méréseket ötszörös ismétléssel végeztük.

\section{Diszkrét elemes szimulációk}

A diszkrét elemes szimuláció lépései mindkét szoftver esetében azonosak voltak. Az első lépés a szemcsék véletlen generálása a modelltérben, melyek a gravitáció hatására lehullnak a modelltér aljára. A kifolyási folyamatot akkor indítottuk el, amikor a rendszer elérte az egyensúlyi állapotot (a korábbiakban bemutatott rezgórendszer lecsillapodott). Ezután a siló alja kinyílt és a siló kiürült. A szimulációs folyamatot a gravitációs „töltéstől” a kiürülésig a 6. ábra mutatja.
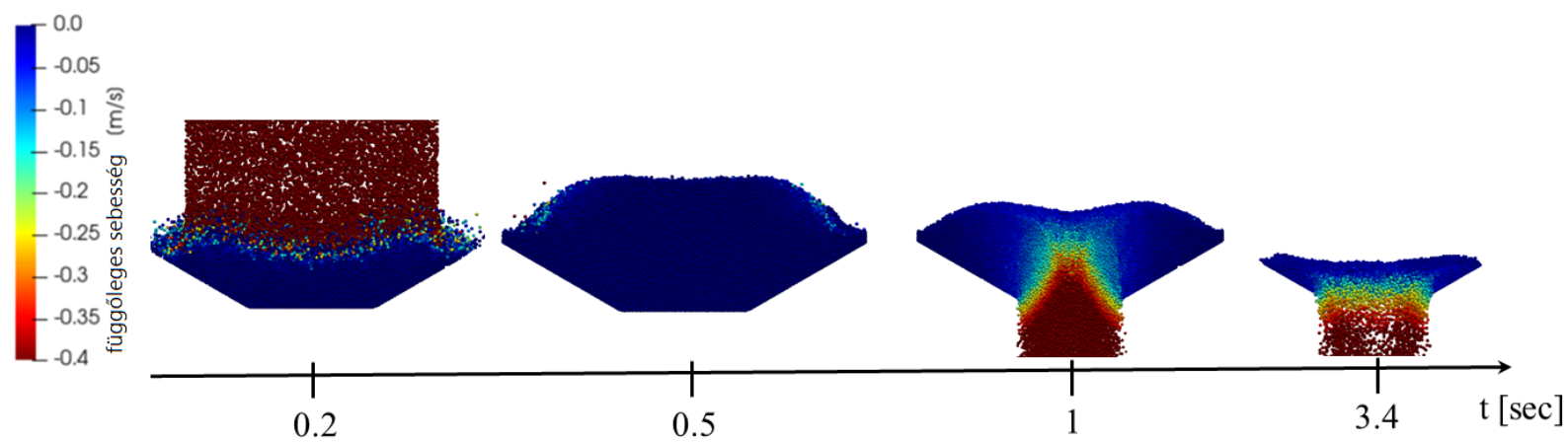

6. ábra. A szimulációs folyamat 

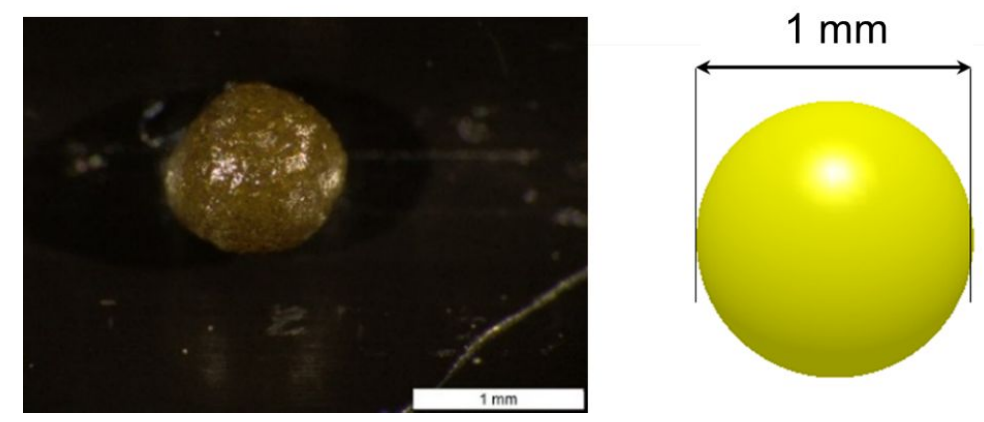

7. ábra. A proppant szemcse mikroszkópos felvétele és diszkrét elemes modellje

A numerikus modell megoldása során a silóban lévő szemcsehalmaz tömegét rögzítettük. A modellezés elsố lépéseként definiálnunk kell a szemcse alakját és méretét, valamint a szemcseméret eloszlást. A proppant szemcsék gömbölyúsége közel 90\%-os, ezért tökéletes gömbként modelleztük a teljes szemcsehalmazt (7. ábra).

Mivel a gyakorlatban alkalmazott proppantok méretének szórása viszonylag kicsi, ezért a szimulációk során valamennyi szemcse átmérője $1 \mathrm{~mm}$ volt. A szemcse-fal és a szemcse-szemcse közötti kölcsönhatások modellezéséhez meg kell adni a súrlódási tényezôt, a gördülési ellenállás tényezőjét, valamint az ütközési tényezôt. Az EDEM szoftver Rayleigh időléptéket használ, mely az ütközések okozta „lökéshullámok” egy szemcsén való áthaladásának idejével kapcsolatos mennyiség. A szimulációk során az alkalmazott idólépték $\Delta t=1,214 \cdot 10^{-5} \mathrm{~s}$ volt. A kezdeti szimulációkat egy korábbi munkánkban [12] meghatározott paraméterekkel indítottuk. Az így kapott eredményeknél azt tapasztaltuk, hogy nem mutatnak jó egyezést a mérési eredményekkel, ezért szükséges volt paraméterek módosítása. Mivel a szemcsehalmazok mechanikai viselkedését nagyban befolyásolják a belső súrlódási viszonyok, ezért a súrlódási tényezôt és a sûrúséget módosítottuk. Az 1. táblázat mutatja a kezdeti és a módosított értékeket.

1. táblázat. A kezdeti és módosított mikromechanikai paraméterek az EDEM szoftverben

\begin{tabular}{l|c|c|c|c}
\multirow{2}{*}{ Mikromechanikai paraméter } & \multicolumn{2}{|c}{ Kezdeti érték } & \multicolumn{2}{c}{ Módosított érték } \\
\cline { 2 - 5 } & proppant & siló & proppant & siló \\
\hline Poisson-tényezô $(\nu)$ & 0,25 & 0,3 & 0,25 & 0,3 \\
Csúsztató rug. modulus $(G),[\mathrm{Pa}]$ & $3,58 \cdot 10^{8}$ & $8 \cdot 10^{8}$ & $3,58 \cdot 10^{8}$ & $8 \cdot 10^{8}$ \\
Sürüség $(\rho),\left[\mathrm{kg} / \mathrm{m}^{3}\right]$ & 3400 & 7500 & 2000 & 7500 \\
Ütközési tényezô proppantra $\left(C_{r}\right),[-]$ & 0,5 & 0,6 & 0,5 & 0,6 \\
Súrlódási tényezó proppantra $\left(\mu_{0}\right),[-]$ & 0,3 & 0,25 & 0,3 & 0,3 \\
Gördülési ellenállás tényezô proppantra $\left(C_{r}\right),[-]$ & 0,01 & 0,01 & 0,01 & 0,01
\end{tabular}

2. táblázat. A kezdeti és módosított mikromechanikai paraméterek a YADE szoftverben

\begin{tabular}{l|c|c|c|c}
\multirow{2}{*}{ Mikromechanikai paraméter } & \multicolumn{2}{|c|}{ Kezdeti érték } & \multicolumn{2}{|c}{ Módosított érték } \\
\cline { 2 - 5 } & proppant & siló & proppant & siló \\
\hline Poisson-tényezô $(\nu)$ & 0,25 & 0,3 & 0,25 & 0,3 \\
Young-modulus $(G),[\mathrm{Pa}]$ & $5 \cdot 10^{10}$ & - & $5 \cdot 10^{10}$ & - \\
Sürúség $(\rho),\left[\mathrm{kg} / \mathrm{m}^{3}\right]$ & 3400 & - & 5000 & - \\
Súrlódási szög proppantra $(\varphi),\left[^{\circ}\right]$ & 2,8 & 2,8 & 10 & 1 \\
Gördülési ellenállás tényezô proppantra $\left(C_{r}\right),[-]$ & $10^{-4}$ & - & $10^{-4}$ & -
\end{tabular}




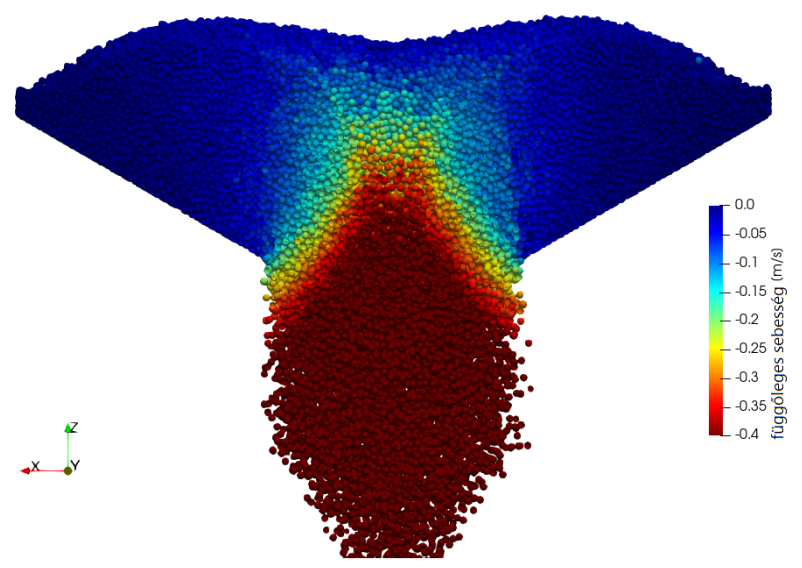

8. ábra. Tölcséres kifolyási mód

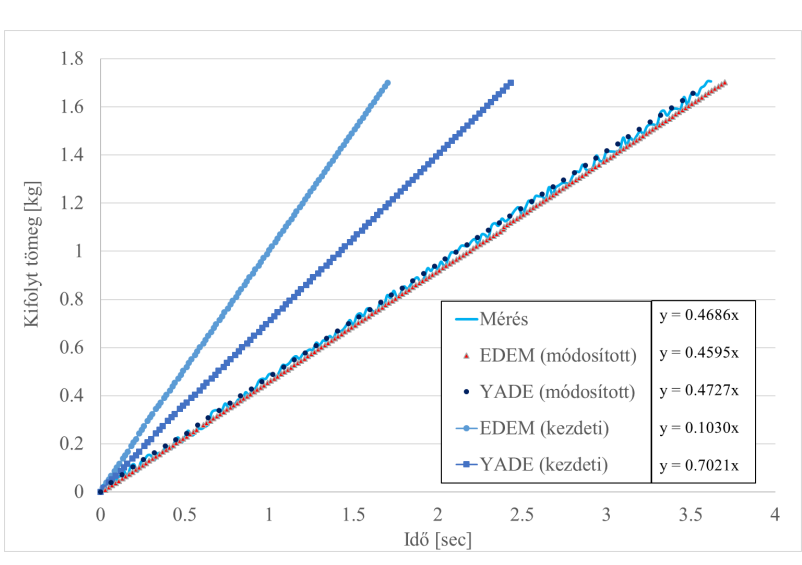

9. ábra. A számított és kísérleti eredmények összehasonlítása

Későbbi vizsgálataink céljából a YADE nyílt forráskódú szoftverkörnyezetben is meghatároztuk a mikromechanikai paramétereket. A YADE megoldója kiszámítja a testekre ható erốk eredôjének és a kölcsönhatásokból származó erők átlagának arányát és így lehetôséget ad a szemcsehalmaz dinamikai viselkedésének nyomon követésére. Statikus egyensúlyi állapotban a testekre ható erôk eredője zérus, ezért az elóbb említett aránynak is zérus értéket kell felvenni, amikor a szimuláció stabilizálódik. Azonban a véges pontosságú számítás miatt soha nem fogja elérni a zérus értéket. Az idólépték ebben az esetben $1,278 \cdot 10^{-5} \mathrm{~s}$ volt. A mikromechanikai paramétereket a 2. táblázat foglalja össze.

A YADE szoftver nagy elônye, hogy a szimulációk Python programozási nyelven megírt segédprogramokkal vezérelhetôk. Az adatok kiértékelése (tömeg-idő diagram felvétele, lineáris regresszió stb.) a számítások elvégzése után automatikusan megtörtént. A szemcsék, sebességmezôk, animációk stb. megjelenítésére a ParaView-t [13] használtuk. A sebességmezốt megvizsgálva megállapítottuk, hogy tölcséres kifolyási mód jött létre az ürítés során (8. ábra). Ezt követően összehasonlítottuk a számított és mért eredményeket és azt tapasztaltuk, hogy jó közelítéssel megegyeznek (9. ábra).

\section{Következtetések}

Jelen tanulmányban megállapítottuk, hogy a diszkrét elemes modellezés alkalmas a hidraulikus rétegrepesztésnél alkalmazott proppant szemcsék mikromechanikai paramétereinek meghatározására. A paraméter identifikációs technikák közül a silókifolyást választottuk. Az eredmények azt mutatták, hogy a BALL típusú és a Hertz-Mindlin kapcsolati modellek és az általunk meghatározott mikromechanikai paraméterek alkalmasak a proppant szemcsék mechanikai viselkedésének leírására. Munkánk során az EDEM és a YADE diszkrét elemes szoftvert használtuk, kihasználva mindkét szoftver előnyeit. További céljaink között szerepel a hidraulikus rétegrepesztés teljesítményének meghatározása diszkrét elemes módszer segítségével.

\section{Köszönetnyilvánítás}

Az Innovációs és Technológiai Minisztérium ÚNKP-20-3 kódszámú Új Nemzeti Kiválóság Programjának a Nemzeti Kutatási Fejlesztési és Innovációs Alapból finanszírozott szakmai támogatásával készült. 


\section{Irodalomjegyzék}

[1] A.D. Taleghani, P. Puyang, B.R. Sarker, Multi-Disciplinary Data Integration for Inverse Hydraulic Fracturing Analysis: A Case Study, Unconventional Resources Technology Conference, San Antonio, Texas, 20-22 July 2015, CrossRef

[2] M.J. Economides, K.G. Nolte, Reservoir Stimulation, 3rd Edition, Wiley, New York, 2000.

[3] M.J. Economides, K.G. Nolte, Modern Fracturing - Enhancing Natural Gas Production, E.T.P. Inc., Houston, 2008.

[4] Lengyel T., Jobbik A., Tóth A., An Analytical Approach for Propped Fracture Conductivity, Conference Proceedings of 18th International Multidisciplinary Scientific Geoconference SGEM, Volume 18, Science and Technologies in Geology, Exploration and Mining - Issue: 1.4, Oil and Gas Exploration, Albena, Bulgaria, 2018.

[5] H. Hertz, Über die Berührung fester elastischer Körper, Gesammelte Werke (P. Lenard, ed.), Bd. 1, (J.A. Barth, Leipzig, 1895) pp. 155-173.

Eredeti megjelenés: Journal f.d. reine u. angewandte Mathematik 92, 1881, pp. 156-171, CrossRef

[6] K. Li, Y. Gao, Y. Lyu, M. Wang, New Mathematical Models for Calculating Proppant Embedment and Fracture Conductivity, SPE Journal 20(03), 2015, pp. 496-507, CrossRef

[7] Bagi K., Fundaments of the discrete element method, egyetemi jegyzet, Budapest University of Technology and Economics, 2012.

[8] C. González-Montellano, Á. Ramírez, E. Gallego, F. Ayuga, Validation and experimental calibration of $3 D$ discrete element models for the simulation of the discharge flow in silos, Chemical Engineering Science 66(21), 2011, pp. 5116-5126, CrossRef

[9] P.A. Cundall, O.D.L. Stack, A discrete numerical model for granular assemblies, Geotechnique 29(1), 1979, pp. 47-65, CrossRef

[10] V. Šmilauer, B. Chareyre, Yade dem formulation, V. Šmilauer (szerk.), Yade Documentation, The Yade Project, 1st ed. részlete, 2010, url

[11] Oldal I., Safranyik F., Extension of silo discharge model based on discrete element method, Journal of Mechanical Science and Technology 29(9), 2015, pp. 3789-3796, CrossRef

[12] Keppler I., Varga A., Szabo I., Katai L., Fenyvesi L., Particle motion around open mixing screws: optimal screw angular velocity, Engineering Computations 33(3), 2016, pp. 896-906, CrossRef

[13] J. Ahrens, B. Geveci, C. Law, ParaView: An End-User Tool for Large Data Visualization, Visualization Handbook, Elsevier, 2005, ISBN-13: 978-0123875822, CrossRef 